Article

\title{
An Experimental Investigation on Tribological Behaviour of Tire-Derived Pyrolysis Oil Blended with Biodiesel Fuel
}

\author{
Haseeb Yaqoob ${ }^{1,2}$, Yew Heng Teoh ${ }^{1, *(\mathbb{D})}$, Muhammad Ahmad Jamil ${ }^{2}$, Tahir Rasheed ${ }^{3}(\mathbb{D}$ \\ and Farooq Sher $4, *$ iD \\ 1 School of Mechanical Engineering, Engineering Campus, Universiti Sains Malaysia, Nibong Tebal, \\ Penang 14300, Malaysia; haseeb.yaqoob@student.usm.my \\ 2 Department of Mechanical Engineering, Khwaja Fareed University of Engineering and Information \\ Technology, Rahim Yar Khan 64200, Pakistan; ahmad.jamil@kfueit.edu.pk \\ 3 School of Chemistry and Chemical Engineering, Shanghai Jiao Tong University, Shanghai 200240, China; \\ masil@sjtu.edu.cn \\ 4 School of Mechanical, Aerospace and Automotive Engineering, Faculty of Engineering, \\ Environmental and Computing, Coventry University, Coventry CV1 5FB, UK \\ * Correspondence: yewhengteoh@usm.my (Y.H.T.); Farooq.Sher@coventry.ac.uk (F.S.)
}

Received: 8 November 2020; Accepted: 24 November 2020; Published: 29 November 2020

check for updates

\begin{abstract}
The demand for alternative fuels has risen in recent years due to the economic and environmental consequences of conventional fuels. In addition to engine characteristics, i.e., performance, combustion, and emission the lubricity of the considered fuel is an important parameter for its selection. This experimental study shows the tribological performance of the tire pyrolysis oil by using the four-ball tester. Waste tire pyrolysis oil was purified by using the distillation process. The experiment was conducted over $300 \mathrm{~s}$ at 40,50,63, and $80 \mathrm{~kg}$ load, $1800 \mathrm{rpm}$ constant speed, and $27^{\circ} \mathrm{C}$ temperature of all fuels on the ASTM D2266 standard. The tribological performance of the tire pyrolysis oil was compared with the BT10 (biodiesel 90\%-tire pyrolysis oil 10\%) and BT20 (biodiesel 80\%-tire pyrolysis oil 20\%) and biodiesel. The optical microscope is used to measure the wear scar diameter and then it is examined through a scanning electron microscope. In terms of greater load-carrying capacity, tire pyrolysis oil shows better anti-wear behaviour compared to biodiesel fuel. The wear scar diameter of BT10, BT20, and tire pyrolysis oil was $23.99 \%, 8.37 \%$, and $32.62 \%$, respectively, lower than the biodiesel fuel at $80 \mathrm{~kg}$ load. The SEM micrographs revealed that tire pyrolysis oil and BT10 displayed lower wear as compared to counterparts. Finally, it is concluded that BT10 is the most suitable fuel in terms of tribological performance.
\end{abstract}

Keywords: renewable; tire pyrolysis oil; sustainable fuels; tribology; four-ball tester and biodiesel

\section{Introduction}

The extinction of fossil fuels, climate change, economic recession, surges in population growth, increasing demand, and declining supply of fuel have highlighted the significance of alternative fuels [1,2]. Two main forms of alternative renewable fuels are food and waste based. Food-based fuels include sunflower, palm oil, and rapeseed, etc. These could result in global issues like deforestation and food shortages worldwide and thus received a lot of criticism [3]. Waste-based fuels and microalgae biodiesel are non-food-based fuels and have very potential as an alternative fuel [4]. However, waste-based fuels are the most potent alternative fuels that can replace conventional fossil fuels [5]. On the other hand, the dumping of solid waste tires results in a plethora of environmental issues [6,7]. According to a report by the European Automotive Manufacturers Association (EAMA), there are 
$\sim 1.35$ billion automobiles on the roads [8] and this amount will increase to 2 billion in the next 15 years [9]. The dumping of waste tires has created huge health and environmental issue around the world. Every year, almost 1 billion tons of tires are discarded worldwide [10]. At present, an estimation is that $\sim 4$ billion waste tires are in stockpiles and landfills globally [6]. A total of 5.26 million tons of tire pyrolysis oil (TPO) can be generated from the 1 billion waste tires [11].

Converting this waste to fuel would not only reduce the problems of waste dumping but can also reduce the pressure on conventional fuels and thus can be an ideal alternative renewable fuel. These waste tires can be processed in a static stirred batch pyrolysis reactor and therefore converted into $44 \%$ char, $49 \%$ oil, and $7 \%$ pyrolytic gases [12]. Accordingly, an estimate shows $44.5 \%$ tire pyrolysis oil can be purified in the form of fuel [13]. TPO is one of the main products of waste automobile tires. Its use as a waste-based alternative fuel in compression ignition engines [14-17], furnaces [18], and boilers [19] has been a topic of interest for researchers. Even though the sulphur content of TPO is notably higher than diesel fuel, however, its calorific value, kinematic viscosity, and density are roughly equivalent [20]. The sulphur content in the fuel tends to increase the lubricity of the fuel [21]. Due to the $0.55-3.95 \%$ sulphur contents, the TPO is desulphurised and distilled [22] to control its permissible limit in the diesel engines.

Biodiesel is among the world's most effective renewable fuels for coping with energy needs. It is derived from various animal fats and vegetable oils [23,24]. Compared to diesel fuel, biodiesel offers technological advantages such as biodegradability, better flash point, cetane number, and lower exhaust emission [25-27]. Biodiesel offers a fundamentally higher lubricity than diesel fuel [28]. The fuel with higher oxygen content leads to more wear. The chemical reaction between unsaturated fatty acids and oxygen comes into contact with metal surfaces [29]. Mujtaba et al., reported that BD30 ( $30 \%$ biodiesel-70\% diesel) $+\mathrm{TiO}_{2}$ additive showed $6.72 \%$ reduction in coefficient of friction (COF) and $38.4 \%$ reduction in wear scar diameter (WSD) as compared to BD30 fuel [30]. In the experimental study, the average palm-sesame oil blend P50S50 (50:50 wt \%) biodiesel friction coefficient was 2.29\% and $12.37 \%$ lower than palm biodiesel and commercial diesel, respectively [31]. With advancements in technology and rapid rejuvenation in the industrial world, the fuels do not only supply energy but is also an essential lubricant [32]. The life of an engine is dependent on its lubricity. Lubricity tends to reduce the consumption of energy and power by reducing the frictional force between moving parts and lubricating the injectors and fuel pumps [33].

The friction and wear mechanism of the fuel engine is hence an essential topic to conduct a study on. The literature lacks studies on the investigation of TPO's tribological characteristics the way there are on engine characteristics, i.e., performance, combustion, and emission in diesel engines [14-18,34-37]. A few examinations have been researched on the wear attributes of the various biodiesel and their mixes with diesel fuel that are presented in Table 1. To focus on this gap, the current study looks at the contact and wear attributes of TPO and their blend with biodiesel fuel at various test boundaries. The tire pyrolysis oil (TPO), palm biodiesel fuel (BD), and their blends BT10 (Biodiesel 90\%, TPO 10\%) and BT20 (Biodiesel 80\%, TPO 20\%) were investigated. Furthermore, the test investigation of contact and wear attributes of TPO is analysed by utilizing the four-ball tribometer (FBT).

Table 1. A summary of the literature review of tribological characteristics of different tested fuels using fourball tester or other equipment.

\begin{tabular}{|c|c|c|c|c|c|}
\hline Tested Samples & Apparatus & Ball Material & Working Conditions & $\begin{array}{l}\text { Tribological Characteristics } \\
\text { Comparison with Diesel }\end{array}$ & References \\
\hline $\begin{array}{c}\text { CIB10, CIB20, } \\
\text { CIB30, CIB50, } \\
\text { CIB100, DF } \\
\text { (Calophyllum } \\
\text { inophyllum }(\mathrm{CI}) \text { ) }\end{array}$ & FBT & $\begin{array}{l}\text { Carbon-chromium } \\
\text { steel }\end{array}$ & $\begin{array}{c}27^{\circ} \mathrm{C} \text {, the normal load } \\
\text { of } 40,50,63 \text {, and } 80 \mathrm{~kg} \\
\text { for } 300 \mathrm{~s} \\
\text { at } 1800 \mathrm{rpm} \text { speed }\end{array}$ & $\begin{array}{l}\text { Friction and wear } \mathbf{\nabla} \text { with the } \\
\mathbf{\Delta} \text { of concentration of } \\
\text { biodiesel and friction and } \\
\text { wear } \boldsymbol{\nabla} \text { with } \boldsymbol{\Delta} \text { of load. }\end{array}$ & [38] \\
\hline
\end{tabular}


Table 1. Cont.

\begin{tabular}{|c|c|c|c|c|c|}
\hline Tested Samples & Apparatus & Ball Material & Working Conditions & $\begin{array}{l}\text { Tribological Characteristics } \\
\text { Comparison with Diesel }\end{array}$ & References \\
\hline $\begin{array}{c}\text { PB10, PB20, } \\
\text { PB100, CIB10, } \\
\text { CIB20, CIB100, } \\
\text { DF } \\
\text { (Palm oil } \\
\text { biodiesel (PB), } \\
\text { Calophyllum }\end{array}$ & FBT & $\begin{array}{l}\text { Carbon-chromium } \\
\text { steel }\end{array}$ & $\begin{array}{c}27^{\circ} \mathrm{C}, 45^{\circ} \mathrm{C}, 60^{\circ} \mathrm{C}, \\
\text { and } 75^{\circ} \mathrm{C}, \text { normal load } \\
\text { of } 40 \text { and } 80 \mathrm{~kg} \text { for } \\
300 \mathrm{~s} \text { at } 1800 \mathrm{rpm} \\
\text { speed }\end{array}$ & $\begin{array}{l}\text { Friction and wear } \mathbf{\nabla} \text { with the } \\
\mathbf{\Delta} \text { of concentration of } \\
\text { biodiesel and friction and } \\
\text { wear } \mathbf{\nabla} \text { with } \boldsymbol{\Delta} \text { load and } \\
\text { temperature. }\end{array}$ & [39] \\
\hline $\begin{array}{l}\text { inophyllum (CI)), } \\
\text { B0, B10, B20, B50, } \\
\text { B100 } \\
\text { (Sunflower, } \\
\text { Soybean) }\end{array}$ & FBT & $\begin{array}{l}\text { Carbon-chromium } \\
\text { steel }\end{array}$ & $\begin{array}{c}75^{\circ} \mathrm{C}, \text { load } 40 \mathrm{~kg} \text { for } \\
300 \mathrm{~s} \text { and } 3600 \mathrm{~s} \text { at } 600, \\
900,1200 \\
\text { and } 1800 \mathrm{rpm}\end{array}$ & $\begin{array}{l}\text { Friction and wear } \mathbf{\nabla} \text { with the } \\
\mathbf{\Delta} \text { of concentration of } \\
\text { biodiesel and friction and } \\
\text { wear } \mathbf{\Delta} \text { with } \mathbf{\Delta} \text { of speed. }\end{array}$ & [40] \\
\hline $\begin{array}{c}\text { MO5, MO8, } \\
\text { MO12 } \\
\text { Mongongo-oil } \\
\text { biodiesel } \\
\text { MO5 (5\% } \\
\text { Mongongo } \\
\text { oil-95\% SAE } \\
\text { 20W-40) }\end{array}$ & $\begin{array}{l}\text { pin-on-disc } \\
\text { tribometer }\end{array}$ & $\begin{array}{l}\text { aluminium-silicon } \\
\text { alloy }\end{array}$ & $\begin{array}{c}27^{\circ} \mathrm{C} \text {, the normal load } \\
\text { of } 40,80, \text { and } 120 \mathrm{~N}, \\
\text { for } 300 \mathrm{~s} \text { and } 3600 \mathrm{~s} \text { at } \\
600,900,1200 \\
\text { and } 1800 \mathrm{rpm} \\
\text { varying speed }\end{array}$ & $\begin{array}{l}\text { Friction } \boldsymbol{\nabla} \text { with the } \boldsymbol{\Delta} \text { load } \\
\text { and wear } \boldsymbol{\Delta} \text { with } \boldsymbol{\Delta} \text { of load. }\end{array}$ & [41] \\
\hline $\begin{array}{l}\text { B0, B5, B20, B100 } \\
\quad \text { (Soybean) }\end{array}$ & $\begin{array}{l}\text { High-frequency } \\
\text { reciprocating rig }\end{array}$ & AISI 52100 steel & $\begin{array}{c}60^{\circ} \mathrm{C}, 1.96 \mathrm{~N} \text { for } \\
75 \text { min at } \\
50 \mathrm{~Hz} \text { frequency }\end{array}$ & $\begin{array}{l}\text { Friction } \Delta \text { with the } \boldsymbol{\Delta} \text { of } \\
\text { concentration of biodiesel. }\end{array}$ & [42] \\
\hline
\end{tabular}

\section{Materials and Methods}

\subsection{Tire Pyrolysis Oil Production and Purification}

The pyrolysis process is used to convert the waste tires to tire pyrolysis oil $(49 \%)$, solid char $(44 \%)$, and pyrolytic gas $(7 \%)$ respectively. The waste tires were condensed and their flow rate differed from 5.5 to $14.5 \mathrm{~kg} / \mathrm{h} \mathrm{[12]}$. The physicochemical properties of raw tire pyrolysis oil are listed in Table 2. It is reported that the viscosity, density, flash point, and calorific value of waste TPO is similar to automotive diesel, but the amount of sulphur is substantially higher than the diesel [20]. The presence of an excess quantity of oxygen content (0.10-3.96\%) in TPO [7] and 10.79\% in biodiesel [43] can minimize friction and wear as compared to diesel [44].

Table 2. The physicochemical properties of raw tire pyrolysis oil.

\begin{tabular}{ccc}
\hline Parameters & ASTM Standard & Raw TPO \\
\hline Calorific value $(\mathrm{MJ} / \mathrm{Kg})$ & ASTM D240 & 43.09 \\
Kinematic viscosity @ $40^{\circ} \mathrm{C}(\mathrm{cSt})$ & ASTM D7042 & 4.74 \\
Density @ $15^{\circ} \mathrm{C}\left(\mathrm{kg} / \mathrm{m}^{3}\right)$ & ASTM D4052 & 927 \\
Flashpoint $\left({ }^{\circ} \mathrm{C}\right)$ & ASTM D93 & $<40$ \\
Pour point $\left({ }^{\circ} \mathrm{C}\right)$ & ASTM D97 & $<40$ \\
Sulphur $($ mass, $\%)$ & ASTM D4294 & 0.77 \\
Ash (mass, $\%)$ & ASTM D462 & 0.009 \\
Carbon residue $(\mathrm{m} / \mathrm{m}, \%)$ & ASTM D4530 & 1.07 \\
Acid number $(\mathrm{mg} \mathrm{KOH} / \mathrm{g})$ & ASTM D664 & 1.03 \\
Water by distillation $(\mathrm{V} / \mathrm{V}, \%)$ & ASTM D95 & 0.10 \\
Sediment by extraction $(\mathrm{m} / \mathrm{m}, \%)$ & ASTM D473 & 0.097 \\
\hline
\end{tabular}

The purification of waste TPO was completed in the research facility. Towards the beginning, waste TPO was warmed at $110{ }^{\circ} \mathrm{C}$ to eliminate its water content. At this point, $8 \% \mathrm{H}_{2} \mathrm{SO}_{4}$ was added to the waste TPO for the hydro sulfuric acid treatment at $70{ }^{\circ} \mathrm{C}$ and mixed with a magnetic stirrer for $4 \mathrm{~h}$. After this cycle, the blend was left for $48 \mathrm{~h}$. At last, the blend was run through a distillation unit. The biodiesel fuel was acquired from a local organization. BT10 and BT20 blends were made by utilizing the magnetic stirrer. The physical properties of biodiesel fuel, BT10, BT20, and tire pyrolysis oil (TPO) are presented in Table 3. The apparatuses utilized in this work are recorded in Table 4. 
Table 3. Different properties of tire pyrolysis oil-biodiesel blended fuels used in the present study.

\begin{tabular}{cccc}
\hline \multirow{2}{*}{ Fuel } & Density & Kinematic Viscosity & Calorific Value \\
\cline { 2 - 4 } & $\mathbf{( k g / \mathbf { m } ^ { \mathbf { 3 } }}$ & $\mathbf{( c S t )}$ & $\mathbf{( M J} / \mathbf{k g})$ \\
\hline & $15^{\circ} \mathrm{C}$ & $40{ }^{\circ} \mathrm{C}$ & \\
Biodiesel & 875.5 & 4.45 & 38.89 \\
BT10 & 886 & 4.21 & 39.26 \\
BT20 & 896 & 4.13 & 39.37 \\
TPO & 946 & 2.23 & 41.81 \\
\hline
\end{tabular}

Table 4. A detailed list of the equipment and instruments used in the present study.

\begin{tabular}{cccccc}
\hline & Standard & Apparatus & Made & Model & Accuracy \\
\hline Calorific value & ASTM D240 & Bomb calorimeter & IKA, UK & C2000 & $\pm 0.1 \% \mathrm{MJ} / \mathrm{kg}$ \\
Kinematic viscosity & ASTM D7042 & Stabinger viscometer & Anton Paar, UK & SVM 3000 & $\pm 0.35 \%$ \\
Density & ASTM D4052 & Stabinger viscometer & Anton Paar, UK & SVM 3000 & $\pm 0.1 \mathrm{~kg} / \mathrm{m}^{3}$ \\
Friction and wear & ASTM D2266 & Four ball testers & DUCOM, India & TR-30L-IAS & - \\
$\begin{array}{c}\text { Wear scar diameter } \\
\text { Scanning electron }\end{array}$ & ASTM D4172 & Optical microscope & IKA, UK & C2000 & $\pm 0.01 \mathrm{~mm}$ \\
microscope (SEM) & X30/X2000 & SEM & Hitachi & S3400N & $3.0 \mathrm{~nm}$ at 30 kV \\
\hline
\end{tabular}

\subsection{Test Setup}

Four ball tribometer (TR-30L-IAS, DUCOM, Bengaluru, Karnataka, India) was utilized during the examination that aided in the research and development of tribology of new oils (shown in Figure 1). It utilized four balls to test the sample however three of those were fixed in the fuel sample bath and one ball was turning that was held by the motor spindle. The schematic diagram of the four-ball tester and the exploratory setup appears in Figure 2. The fuel/oil bath was loaded up with the tested fuel. The highlights of the fourball tester are recorded in Table 5.

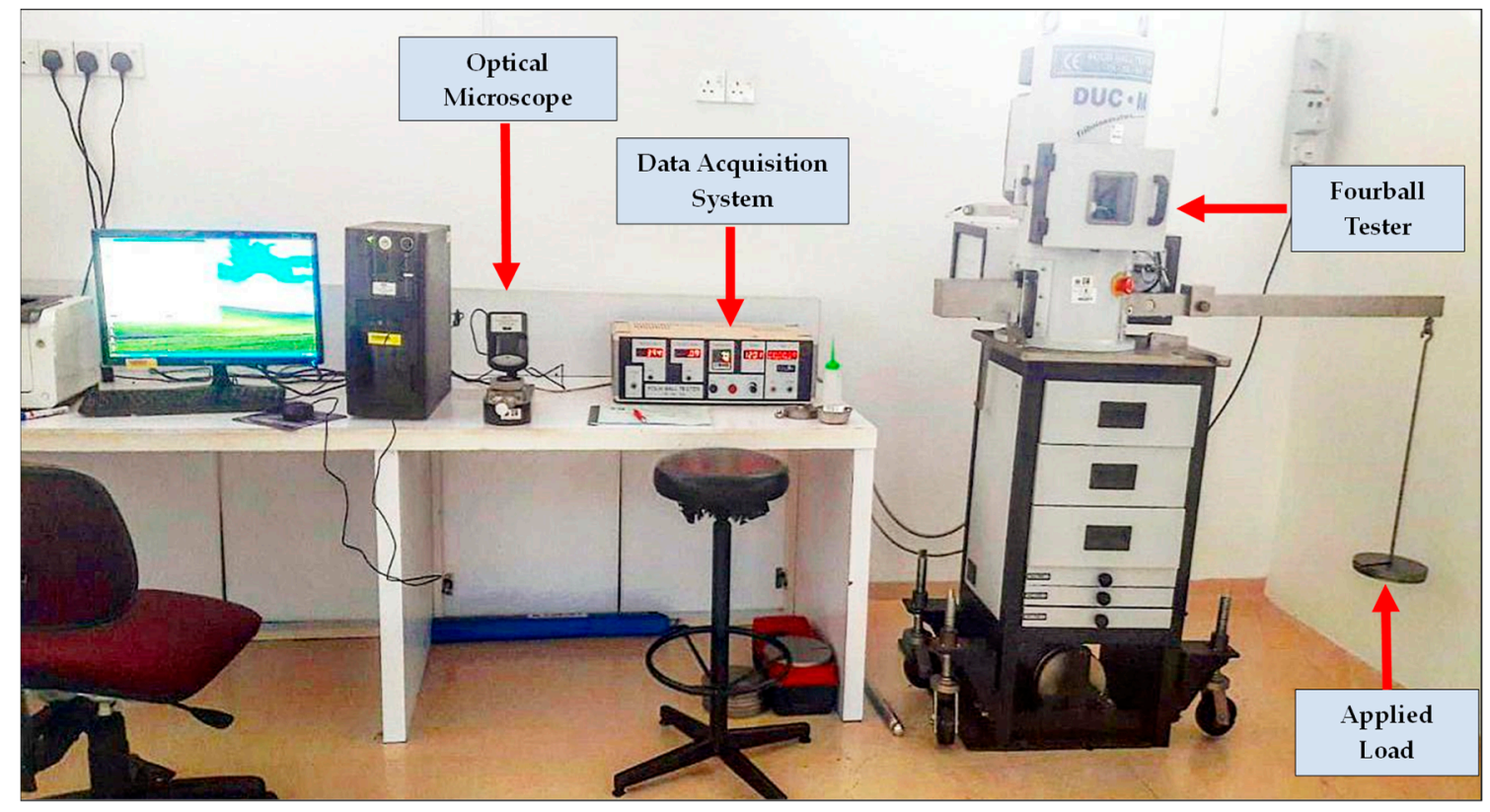

Figure 1. The experimental setup used in the current study. 


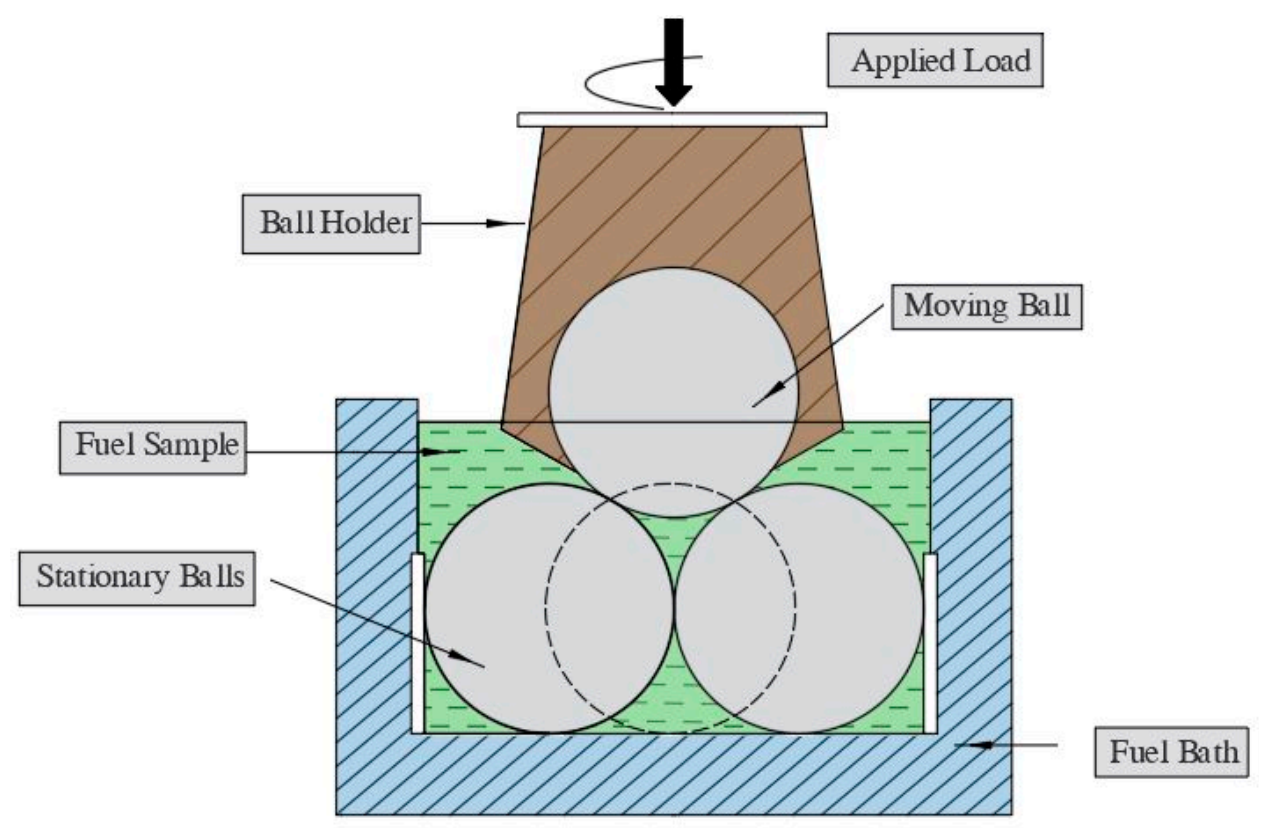

Figure 2. The schematic representation of four-ball tribometer geometry.

Table 5. The key features of four-ball tester, data acquisition system and optical microscope.

\begin{tabular}{cccc}
\hline Specification & Units & Detail & Accuracy \\
\hline Model & - & Make: DUCOM TR-30L-IAS & \\
Speed & $\mathrm{RPM}$ & $300-3000$ & 1 \\
Oil Temperature & ${ }^{\circ} \mathrm{C}$ & Ambient temperature to 100 & 0.5 \\
Maximum axial load & $\mathrm{N}$ & 10,000 & 0.5 \\
Range of scar & $\mu \mathrm{m}$ & $100-4000$ & 0.5 \\
Diameter of ball & $\mathrm{mm}$ & 12.7 & \\
Image measuring system & & Optical microscope \\
Image acquisition system & & Make: Radical instrument, 220 $\mathrm{V}, 50 \mathrm{~Hz}$ \\
Software & $\quad$ Web camera, 12 megapixels \\
& & Winducom 2010 \\
\hline
\end{tabular}

The lever arm was utilized to apply loads on the balls fixed at the bottom and frictional torque was determined by the balanced arm utilizing a spring connected to a friction recording apparatus. The carbon-chromium steel balls were utilized in this investigation and the details of the balls are recorded in Table 5. Four new balls were cleaned with acetone and dried using air and tissue paper.

\subsection{Test Procedure}

Acetone was used to clean the four steel balls and oil cups to remove the dust particles and oil before each experiment. In accordance with the recommended torque, the 03 steel balls were locked in the cup, and then test oil was poured into the oil cup until the 03 steel balls were completely covered. 01 ball clutched and then fixed within the apparatus. The oil cup was placed inside the apparatus and the controller cable was attached to it. ASTM standard D2266 was used for these experiments. The duration was $300 \mathrm{~s}$ at $1800 \mathrm{rpm}$ constant spindle speed with 40, 50, 63, and $80 \mathrm{~kg}$ loads at an oil temperature of $27^{\circ} \mathrm{C}$. The software (Winducom 2010) was used to measure and evaluate the readings at the decided varying parameters. Table 6 shows the experimental requirements for four-ball experiments. The three steel balls in the oil cup were acquired at the end of the experiment to measure the wear scar's diameter using an optical microscope and for SEM study. 
Table 6. The experimental conditions and parameters for four-ball test used in the study.

\begin{tabular}{cc}
\hline Parameter & Values \\
\hline Standard & ASTM D2266 \\
Speed $(\mathrm{rpm})$ & 1800 \\
Load $(\mathrm{kg})$ & $40,50,63$ and 80 \\
Temperature of Fuel $\left({ }^{\circ} \mathrm{C}\right)$ & 27 \\
Time $(\mathrm{s})$ & 300 \\
Material of Ball & Carbon-chromium steel (SKF) \\
Composition & $0.06 \% \mathrm{Ni} ; 1.46 \%$ Cr; $0.12 \% \mathrm{P} ; 2.15 \% \mathrm{Zn}$ \\
Ball Diameter $(\mathrm{mm})$ & 12.7 \\
Ball Hardness $(\mathrm{HRc})$ & 62 \\
Ball Surface roughness $(\mu \mathrm{m})$ & $0.1 \mathrm{C}$.L.A \\
\hline
\end{tabular}

\subsubsection{Friction Evaluation}

The software (Winducom 2010) used in the measurement of the value of friction's mean coefficient by using the Equations (1) and (2) [38]. Frictional torque is measured by using a load cell in the apparatus.

$$
\begin{gathered}
T=\frac{\mu \times r \times 3 W}{\sqrt{6}} \\
\mu=\frac{T \times \sqrt{6}}{r \times 3 W}
\end{gathered}
$$

where $\mu$ is the friction coefficient, $T$ is the frictional torque (N.m), $W$ is the applied load (N) and $r$ is the distance defined to be $3.67 \mathrm{~mm}$ from the middle of the contact surface on the lower balls to the rotation axis.

\subsubsection{Flash Temperature Parameter}

The flash temperature parameter (FTP) of all fuels were measured using Equation (3) [38]. It is an important parameter for the lubricants to portray the critical flash temperature under the input conditions of the four-ball test.

$$
F T P=\frac{F}{D^{1.4}}
$$

where $F$ is the applied load $(\mathrm{kg})$ and $D$ is the average WSD $(\mathrm{mm})$.

\subsubsection{Wear Evaluation}

As per standard ASTM D4172, the optical microscope was used to measure the wear scar diameter of the steel balls at a resolution of $0.01 \mathrm{~mm}$. [38]. The optical microscope used the computer's software (Scar View 2005) to capture the wear scar image. In addition, the wear scar diameter using this Scar View 2005 was measured.

\section{Results and Discussion}

\subsection{Friction Behaviour}

The frictional performance was unstable due to the run-in period of the testing at the start of the experiment. The balanced friction behaviour was reported after a couple of seconds and it is called the steady-state condition. The steady-state point is reached over time. This result is due to the fact that, at the start, the surface layer is scratchy. The surface of the tested balls is smoothed a few minutes later by eliminating prominent asperity. The run-in period coefficient of friction was shown in the first $10 \mathrm{~s}$, and the mean steady-state coefficient of friction for the last $100 \mathrm{~s}$ was recorded and presented in Figure 3. 

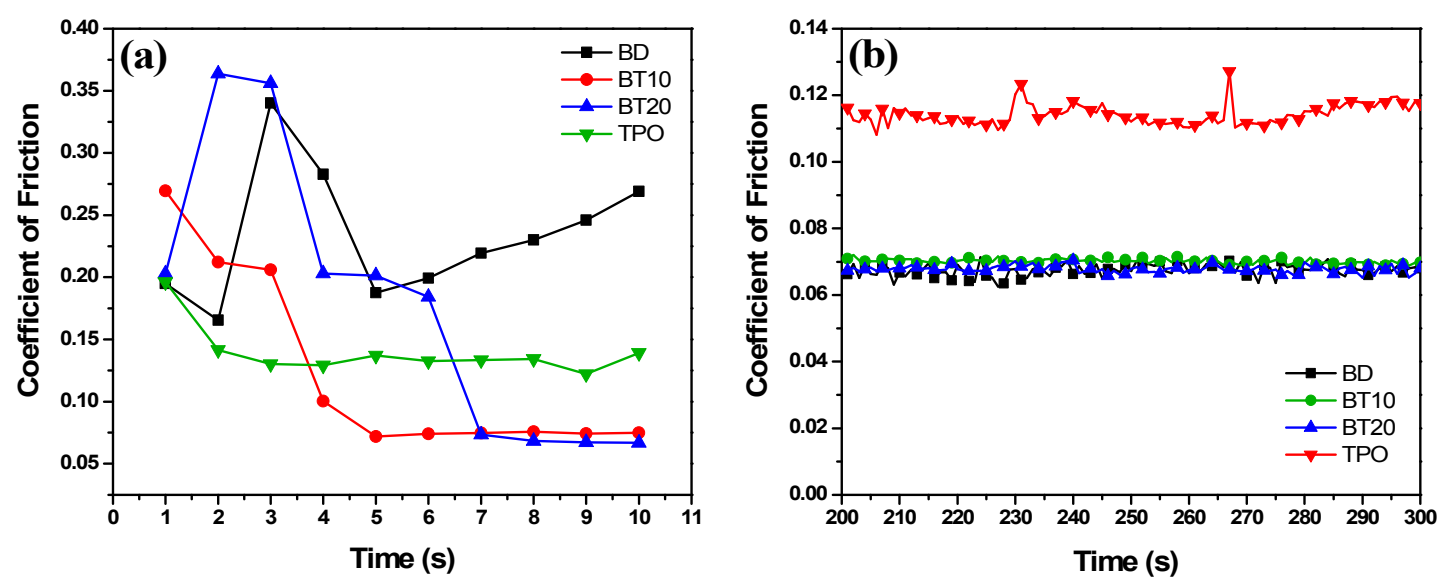

Figure 3. The friction coefficient performance of tire pyrolysis oil-biodiesel blended fuel with time; (a) Run-in period and (b) Steady-state condition.

Biodiesel is shown to have a relatively higher run-in period friction coefficient over a longer period of time than the other fuel samples. TPO produces better friction protection performance than biodiesel and blended fuel samples. Mello et al. reported [21] that the higher sulphur content tends to increase the lubricity. Therefore, TPO performs better lubricity performance due to higher sulphur content as compared to biodiesel fuel that is why TPO, BT10, and BT20 shown an unsteady friction coefficient of $41,49.66$, and $28.63 \%$ respectively, lower than biodiesel fuel. In contrast to biodiesel TPO, BT10 and BT20 displayed a smooth mechanism of the steady-state coefficient of friction that confirms a fluctuating pattern.

Wain et al. [44] stated that biodiesel containing more oxygen can minimize friction and wear. The coefficient of friction performance of BT10 and BT20 is relatively similar to biodiesel fuel in the case of a steady-state condition. According to the test conditions adopted at the boundary, the viscosity of lubricating oils is the key parameter that affects the film thickness separating the surfaces and therefore determines the friction behaviour [45]. In view of the importance of the viscosity of the lubricating oil considered, higher temperatures were observed in the fourball contact geometry, resulting in a reduction in the viscosity of the oil and a higher average coefficient of friction. The comparison of friction profiles therefore showed poor TPO friction activity.

\subsection{Wear Behaviour}

The metal to metal contact contributes to the battering of the collaborating tribo-pair under minimal grease conditions. Figure 4 demonstrates the wearing actions of all of the tested fuel considered. The investigation clearly shows that a bad anti-wear mechanism has been demonstrated by TPO at low loads such as 40,50, and $63 \mathrm{~kg}$. However, better wear prevention is noticed by TPO at a higher load of $80 \mathrm{~kg}$. This pattern has shown the high load carrying limit of TPO. The potential rises in contact temperatures at higher loads resulted in low viscous oils that enhanced the chances of tribo-pair surface contact. As compared with BD, TPO, and BT20 at both low and high loads, BT10 demonstrated a better anti-wear mechanism. The WSD of BT10, BT20, and TPO was $23.99,8.37$, and $32.62 \%$ respectively that was lower than the biodiesel fuel at the $80 \mathrm{~kg}$ load. High sulphur content in TPO reduces the wear behaviour and their blend with biodiesel helps to increase the lubricating properties [46]. Biodiesel has no sulphur content that caused the problems in the lubricity, but Mello et al. also reported [21] that the higher sulphur content tends to increase the lubricity. 


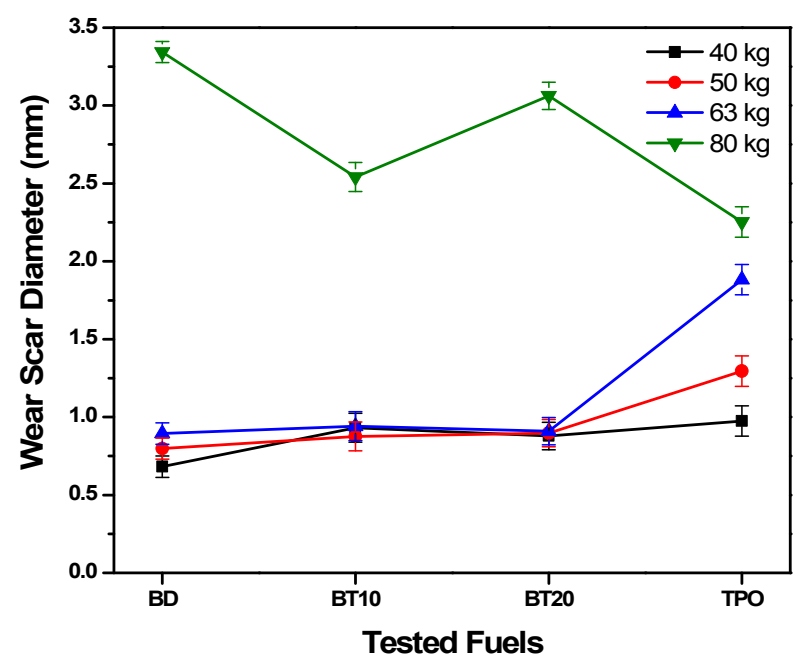

Figure 4. Wear scar diameter of tire pyrolysis oil-biodiesel blended fuels at varying loads.

\subsection{Flash Temperature Parameter}

The result of tested fuels on the flash temperature parameter (FTP) is presented in Figure 5. Strong lubricating efficiency and a low chance of lubricant layer breakdown lead to a high FTP value. The temperature at which a lubricating layer can be formed to enhance lubricity is flash temperature. A higher FTP value leads to better lubricating performance and reduced risks of lubricant film breakdown [47]. The FTP value for each tested fuel rises with a reduction in the wear load. The findings show that the load increase appears to increase the worn surface's WSD as well and FTP is inversely proportional to wear scar diameter [48]. Compared to other fuels, TPO displayed the highest FTP of $25.67^{\circ} \mathrm{C}$ at $80 \mathrm{~kg}$ load. The better FTP results are shown by BT10 and BT20 and that is similar to biodiesel fuel. However, biodiesel fuel $\left(14.77^{\circ} \mathrm{C}\right)$ has been credited with the lowest $F T P$ rating at $80 \mathrm{~kg}$, because of the biodiesel deterioration. Hence, the contact surfaces surround each other and enhance the surface of the contact [49].

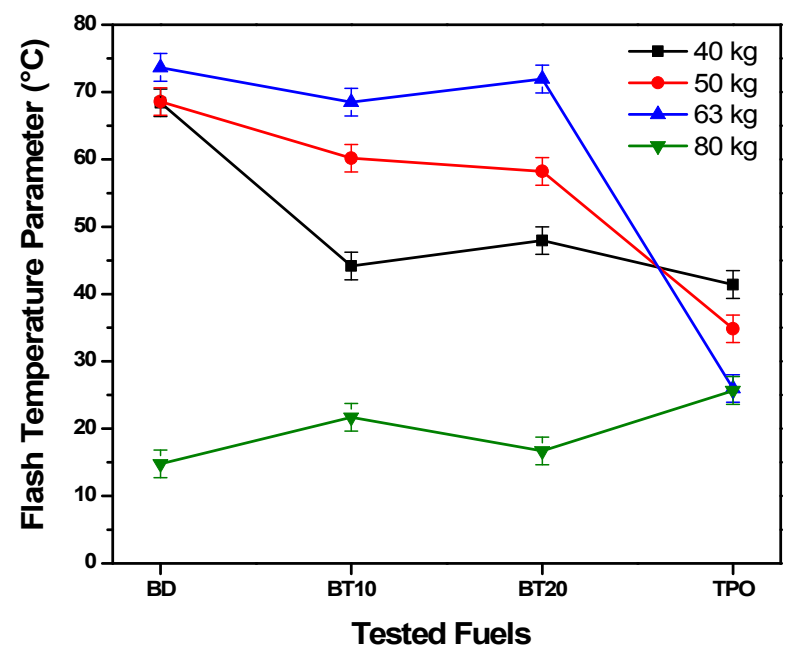

Figure 5. The effect of tire pyrolysis oil-biodiesel blended fuels on flash temperature parameter at varying loads.

\subsection{Morphological Analysis}

Tested ball worn surfaces were characterized by scanning electron microscopy (SEM) to understand the anti-wear behaviour of considered fuel samples. The related worn surfaces were also analysed using SEM, TPO showed better wear prevention at higher loads $(80 \mathrm{~kg})$. For the fuel samples tested, 
Figure 6a-l displays the SEM micrographs of the worn surfaces of the tested balls under $80 \mathrm{~kg}$. The micrographs of the biodiesel showing adhesive wear and rough surface area as clear in Figure $6 \mathrm{a}-\mathrm{c}$ above the TPO blended samples Figure $6 \mathrm{~d}-1$. Similarly, the least material removal is presented in Figure $6 \mathrm{~d}-\mathrm{f}$ relative to Figure $6 \mathrm{~g}-1$. For all tested fuels, the surface wear is greater than $20 \mu \mathrm{m}$, thus representing adhesive wear [50]. As the TPO blend ratio increases, the wear scar diameter leads to an increase. The SEM images also demonstrate that the metal layers are separated from the surfaces in the direction in which the spinning ball rotates. Wain et al. reported that [44] the alternative fuels that have oxygen content may contribute to lower diesel engine emissions but compared to higher sulphur fuels, they may also have lower anti-wear properties.

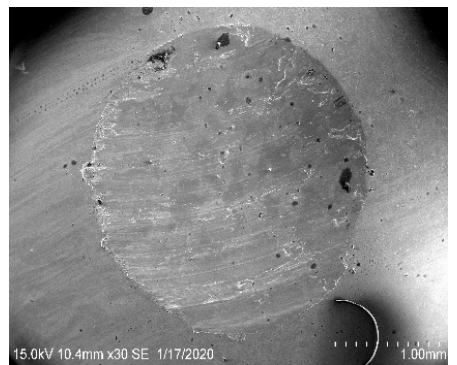

(a) Biodiesel-30x

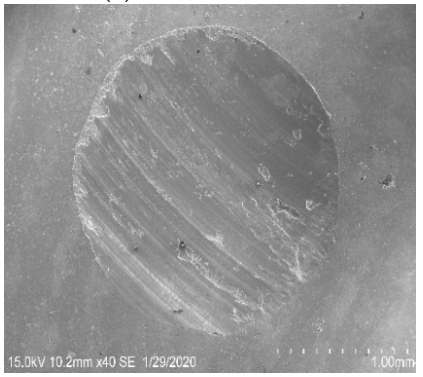

(d) BT10-40x

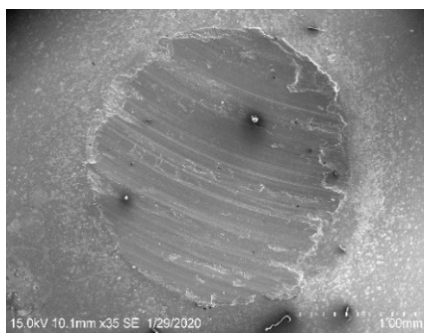

(g) BT20-35×

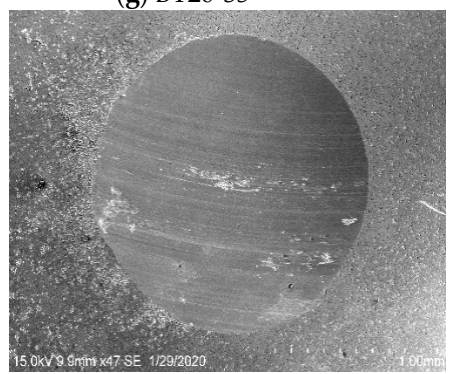

(j) TPO-47x

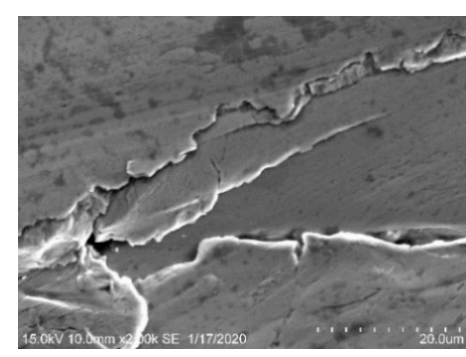

(b) Biodiesel-2.00 kx

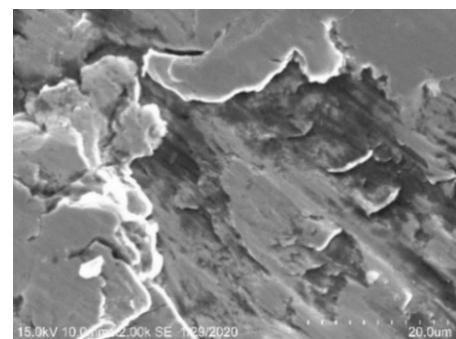

(e) BT10-2.00 kx

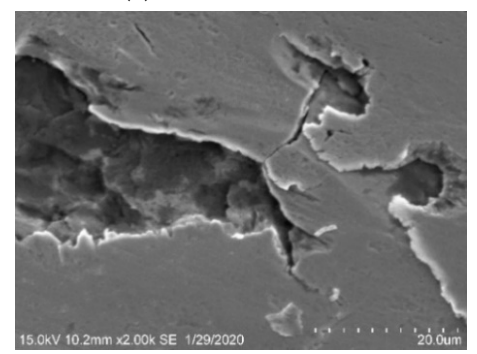

(h) BT20-2.00 kx

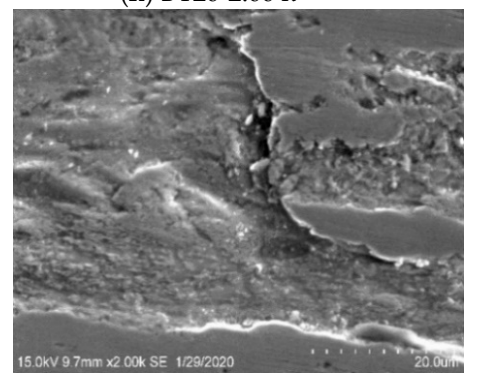

(k) TPO-2.00 kx

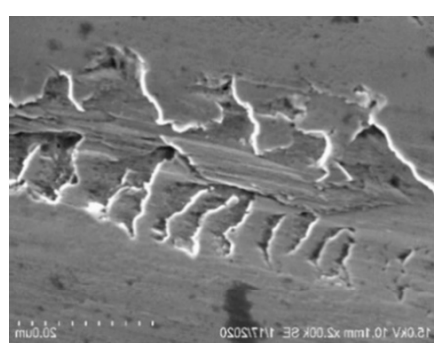

(c) Biodiesel-2.00 kx

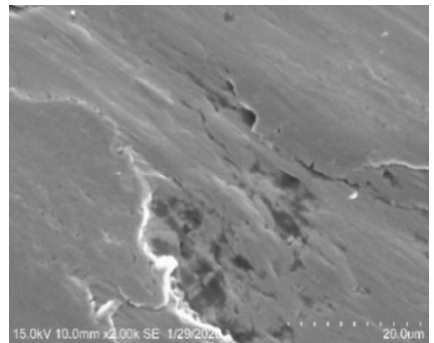

(f) BT10-2.00 kx

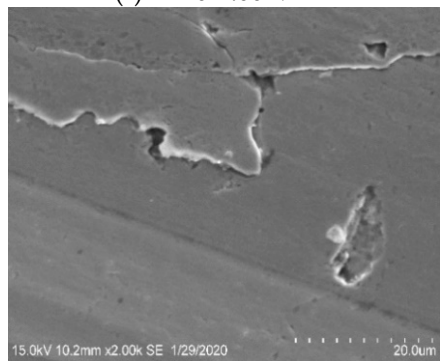

(i) $\mathrm{BT} 20-2.00 \mathrm{kx}$

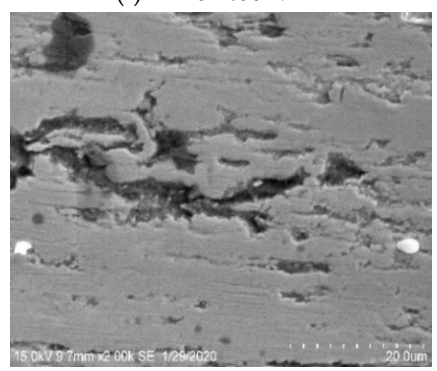

(1) TPO-2.00 kx

Figure 6. The micrograph of the wear scar and distribution of Biodiesel, BT10, BT20 and TPO (a) Biodiesel wear scar (30x), (b) Biodiesel distribution (2 kx), (c) Biodiesel distribution (2 kx), (d) BT10 wear scar (40×), (e) BT10 distribution (2 k×), (f) BT10 distribution (2 k×), (g) BT20 wear scar (35×), (h) BT20 distribution $(2 \mathrm{k} \times)$, (i) BT20 distribution $(2 \mathrm{k} \times)$, (j) TPO wear scar $(47 \times)$, (k) TPO distribution $(2 \mathrm{k} \times)$ and (l) TPO distribution (2 k× ). 


\section{Conclusions}

This experimental study identifies the tribological performance of the tire-derived pyrolysis oil blended with biodiesel fuel by using a fourball tester. The experiment was conducted over $300 \mathrm{~s}$ at $40,50,63$, and $80 \mathrm{~kg}$ load, $1800 \mathrm{rpm}$ constant speed, and $27^{\circ} \mathrm{C}$ temperature of all fuels on the ASTM D2266 standard. The tribological performance of the TPO was compared with the BT10 (Biodiesel 90\%, TPO 10\%) and BT20 (Biodiesel 80\%, TPO 20\%) and biodiesel. Fourball tester is a basic test rig that is generally used in the lubricant industry to assist with new lubricant or grease research and growth. Therefore, it is used to study the tribological performance of the TPO blended with biodiesel fuel. The major findings of this experimental study are as follows:

1. BT10, BT20, and TPO have $49.66 \%, 28.63 \%$, and $41 \%$ lower unsteady coefficient of friction, respectively, than biodiesel. In contrast to the variable performance of biodiesel fuel, the BT10 and TPO showed a smooth behaviour of the unsteady friction coefficient.

2. In comparison to biodiesel fuel, at low and high loads, TPO and BT10 exhibit better wear patterns. The WSD of TPO, BT10, and BT20 were as 32.62\%, 23.99\% and 8.37\%, respectively, lower than the biodiesel fuel at $80 \mathrm{~kg}$ load. The higher sulphur content in the TPO shows better anti-wear behaviour.

3. TPO demonstrates a higher load-carrying capacity that reflects its ability to be used in higher loads and extreme situations of pressure.

4. The wear behaviour of fuel blends tested suggests that for a particular application, moderate friction behaviour, as well as higher load-carrying capacity, can be achieved.

5. Compared to other fuels, TPO has a maximum FTP of $25.67^{\circ} \mathrm{C}$ at $80 \mathrm{~kg}$ load. The FTP results shown by BT10 and BT20 are similar to biodiesel fuel at low loads but a better performance of BT10 and BT20 at high loads. However, biodiesel fuel $\left(14.77^{\circ} \mathrm{C}\right)$ was rated with the lowest FTP value.

6. The SEM micrographs revealed that BT10 and BT20 showed lower metal extrusion compared to biodiesel fuel. Morphology showed that biodiesel fuel particles are broad and are shortened with the rise in the percentage of TPO.

The result of the study suggests that in terms of friction and wear BT10 showed favourable tribological performance. Therefore, it can be used to enhance an engine's life. In addition, tire pyrolysis oil blended with various oils (Fat oil biodiesel, jatropha biodiesel, microalgae biodiesel, and plastic oil etc.) could be used in future work to reduce engine wear. To increase the tribological efficiency, various additives and nanoparticles may be added to increase the desired properties in the TPO blended fuel.

Author Contributions: “Conceptualization, Methodology, Software, Validation, Formal Analysis, Investigation, Resources, Data Curation, Visualization, Writing-Original Draft Preparation, H.Y., Y.H.T. and M.A.J.; Project Administration, Funding Acquisition, Y.H.T.; Writing-Original Draft Preparation, Software, Formal Analysis, Validation, Project Administration, Supervision, Writing-Review and Editing, T.R. and F.S." All authors have read and agreed to the published version of the manuscript.

Funding: This research was funded Ministry of Higher Education (MOHE) of Malaysia under Fundamental Research Grant Scheme (FRGS) [203.PMEKANIK.6071444] and Universiti Sains Malaysia.

Acknowledgments: The authors are grateful for the financial support from the Ministry of Higher Education (MOHE) of Malaysia under Fundamental Research Grant Scheme (FRGS) [203.PMEKANIK.6071444] and Universiti Sains Malaysia.

Conflicts of Interest: The authors declare no conflict of interest.

\section{References}

1. Murugesan, A.; Umarani, C.; Subramanian, R.; Nedunchezhian, N. Bio-diesel as an alternative fuel for diesel engines-A review. Renew. Sustain. Energy Rev. 2009, 13, 653-662. [CrossRef]

2. Dhar, A.; Agarwal, A.K. Performance, emissions and combustion characteristics of Karanja biodiesel in a transportation engine. Fuel 2014, 119, 70-80. [CrossRef] 
3. Lam, M.K.; Tan, K.T.; Lee, K.T.; Mohamed, A.R. Malaysian palm oil: Surviving the food versus fuel dispute for a sustainable future. Renew. Sustain. Energy Rev. 2009, 13, 1456-1464. [CrossRef]

4. Han, X.; Zeng, H.; Bartocci, P.; Fantozzi, F.; Yan, Y. Phytohormones and effects on growth and metabolites of microalgae: A review. Fermentation 2018, 4, 25. [CrossRef]

5. Duan, P.; Jin, B.; Xu, Y.; Wang, F. Co-pyrolysis of microalgae and waste rubber tire in supercritical ethanol. Chem. Eng. J. 2015, 269, 262-271. [CrossRef]

6. Mokhtar, N.M.; Omar, R.; Idris, A. Microwave Pyrolysis for Conversion of Materials to Energy: A Brief Review. Energy Sources Part A Recovery Util. Environ. Eff. 2012, 34, 2104-2122. [CrossRef]

7. Verma, P.; Zare, A.; Jafari, M.; Bodisco, T.A.; Rainey, T.; Ristovski, Z.D.; Brown, R.J. Diesel engine performance and emissions with fuels derived from waste tyres. Sci. Rep. 2018, 8, 2457. [CrossRef]

8. ACEA. ACEA Pocket Guide; European Automobile Manufacturers' Association: Brussel, Belgium, 2016.

9. Voelcker, J. 1.2 Billion Vehicles On World's Roads Now, 2 Billion By 2035: Report. Available online: https://www.greencarreports.com/news/1093560_1-2-billion-vehicles-on-worlds-roads-now-2-billion-by2035-report (accessed on 18 October 2018).

10. Liu, L.; Cai, G.; Zhang, J.; Liu, X.; Liu, K. Evaluation of engineering properties and environmental effect of recycled waste tire-sand/soil in geotechnical engineering: A compressive review. Renew. Sustain. Energy Rev. 2020, 126, 109831. [CrossRef]

11. Islam, M.N.; Nahian, M.R. Improvement of Waste Tire Pyrolysis Oil and Performance Test with Diesel in CI Engine. J. Renew. Energy 2016, 2016, 1-8. [CrossRef]

12. Li, W.; Huang, C.; Li, D.; Huo, P.; Wang, M.; Han, L.; Chen, G.; Li, H.; Li, X.; Wang, Y.; et al. Derived oil production by catalytic pyrolysis of scrap tires. Chin. J. Catal. 2016, 37, 526-532. [CrossRef]

13. Khan, M.Z.H.; Ikram Hossain, M.D.; Pobitra Kumar Halder, M.D.; Rafiul Hasan, M.R.A.-M. Fuel Properties of Pyrolytic Tyre Oil and Its Blends with Diesel Fuel—Towards Waste Management. Int. J. Environ. Waste Manag. 2016, 18, 335-348. [CrossRef]

14. Pinto, G.M.; De Souza, T.A.Z.; Coronado, C.J.R.; Flôres, L.F.V.; Chumpitaz, G.R.A.; Silva, M.H. Experimental Investigation of the Performance and Emissions of a Diesel Engine Fuelled by Blends Containing Diesel S10, Pyrolysis Oil from Used Tires and Biodiesel from Waste Cooking Oil. Environ. Prog. Sustain. Energy 2019, 38, 13199. [CrossRef]

15. Karagoz, M.; Uysal, C.; Agbulut, U.; Saridemir, S. Energy, exergy, economic and sustainability assessments of a compression ignition diesel engine fueled with tire pyrolytic oil-diesel blends. J. Clean. Prod. 2020, 264, 121724. [CrossRef]

16. Pote, R.N.; Patil, R.K. Combustion and emission characteristics analysis of waste tyre pyrolysis oil. SN Appl. Sci. 2019, 294. [CrossRef]

17. Solmaz, H.; Yilmaz, E.; Yes, D. Production of waste tyre oil and experimental investigation on combustion, engine performance and exhaust emissions. J. Energy Inst. 2019, 92, 1406-1418. [CrossRef]

18. Sharma, A.; Murugan, S. Potential for using a tyre pyrolysis oil-biodiesel blend in a diesel engine at different compression ratios. Energy Convers. Manag. 2015, 93, 289-297. [CrossRef]

19. García-Contreras, R.; Martínez, J.D.; Armas, O.; Murillo, R.; García, T. Study of a residential boiler under start-transient conditions using a tire pyrolysis liquid (TPL)/diesel fuel blend. Fuel 2015, 158, 744-752. [CrossRef]

20. Singh, D.; Soni, S.L.; Sharma, D.; Kumari, D. Waste Tyre Oil as Alternative Fuel in CI Engine: A Review. Int. J. Adv. Res. Innov. Ideas Educ. 2017, 3, 577-585.

21. Silva e Mello, V.; Do Vale Souza, E.R.; De Araújo Oliveira, M.V.; Alves, S.M. Effect of desulfurization of diesel and its blends with biodiesel on metallic contact. Mater. Res. 2014, 17, 82-88. [CrossRef]

22. Quek, A.; Balasubramanian, R. Liquefaction of waste tires by pyrolysis for oil and chemicals-A review. J. Anal. Appl. Pyrolysis 2013, 101, 1-16. [CrossRef]

23. Ushakov, S.; Valland, H.; Æsøy, V. Combustion and emissions characteristics of fish oil fuel in a heavy-duty diesel engine. Energy Convers. Manag. 2013, 65, 228-238. [CrossRef]

24. Demirbas, A. Progress and recent trends in biodiesel fuels. Energy Convers. Manag. 2009, 50, 14-34. [CrossRef]

25. Fazal, M.A.; Haseeb, A.S.M.A.; Masjuki, H.H. Biodiesel feasibility study: An evaluation of material compatibility; Performance; emission and engine durability. Renew. Sustain. Energy Rev. 2011, 15, 1314-1324. [CrossRef] 
26. Kannan, D.; Pachamuthu, S.; Nurun Nabi, M.; Hustad, J.E.; Løvås, T. Theoretical and experimental investigation of diesel engine performance, combustion and emissions analysis fuelled with the blends of ethanol, diesel and jatropha methyl ester. Energy Convers. Manag. 2012, 53, 322-331. [CrossRef]

27. Ozsezen, A.N.; Canakci, M. Determination of performance and combustion characteristics of a diesel engine fueled with canola and waste palm oil methyl esters. Energy Convers. Manag. 2011, 52, 108-116. [CrossRef]

28. Haseeb, A.S.M.A.; Sia, S.Y.; Fazal, M.A.; Masjuki, H.H. Effect of temperature on tribological properties of palm biodiesel. Energy 2010, 35, 1460-1464. [CrossRef]

29. Celik, I.; Aydin, O. Effects of B100 Biodiesel on Injector and Pump Piston. Tribol. Trans. 2011, 54, 424-431. [CrossRef]

30. Mujtaba, M.A.; Masjuki, H.H.; Kalam, M.A.; Noor, F.; Farooq, M.; Ong, H.C.; Gul, M.; Soudagar, M.E.M.; Bashir, S.; Rizwanul Fattah, I.M.; et al. Effect of Additivized Biodiesel Blends on Diesel Engine Performance, Emission, Tribological Characteristics, and Lubricant Tribology. Energies 2020, 13, 3375. [CrossRef]

31. Mujtaba, M.A.; Masjuki, H.H.; Kalam, M.A.; Ong, H.C.; Gul, M.; Farooq, M.; Soudagar, M.E.M.; Ahmed, W.; Harith, M.H.; Yusoff, M.N.A.M. Ultrasound-assisted process optimization and tribological characteristics of biodiesel from palm-sesame oil via response surface methodology and extreme learning machine-Cuckoo search. Renew. Energy 2020, 158, 202-214. [CrossRef]

32. Chauhan, B.S.; Kumar, N.; Cho, H.M. A study on the performance and emission of a diesel engine fueled with Jatropha biodiesel oil and its blends. Energy 2012, 37, 616-622. [CrossRef]

33. Serrano, L.M.V.; Câmara, R.M.O.; Carreira, V.J.R.; Gameiro da Silva, M.C. Performance study about biodiesel impact on buses engines using dynamometer tests and fleet consumption data. Energy Convers. Manag. 2012, 60, 2-9. [CrossRef]

34. Thangavelu, S.K.; Arthanarisamy, M. Experimental investigation on engine performance, emission, and combustion characteristics of a DI CI engine using tyre pyrolysis oil and diesel blends doped with nanoparticles. Environ. Prog. Sustain. Energy 2020, 39, e13321. [CrossRef]

35. Vihar, R.; Seljak, T.; Rodman Oprešnik, S.; Katrašnik, T. Combustion characteristics of tire pyrolysis oil in turbo charged compression ignition engine. Fuel 2015, 150, 226-235. [CrossRef]

36. Hamzah, M.H.; Alias, A.; Mamat, R.; Abdullah, A.A. Performance analysis of diesel engine running with tyre-derived fuel. In Proceedings of the 1st International Postgraduate Conference on Mechanical Engineering, Pahang, Malaysia, 17 January 2019; pp. 1-10.

37. Hurdogan, E.; Ozalp, C.; Kara, O.; Ozcanli, M. Experimental investigation on performance and emission characteristics of waste tire pyrolysis oil diesel blends in a diesel engine. Int. J. Hydrogen Energy 2017, 42, 23373-23378. [CrossRef]

38. Habibullah, M.; Masjuki, H.H.; Kalam, M.A.; Zulkifli, N.W.M.; Masum, B.M.; Arslan, A.; Gulzar, M. Friction and wear characteristics of Calophyllum inophyllum biodiesel. Ind. Crop. Prod. 2015, 76, 188-197. [CrossRef]

39. Mosarof, M.H.; Kalam, M.A.; Masjuki, H.H.; Alabdulkarem, A.; Habibullah, M.; Arslan, A.; Monirul, I.M. Assessment of friction and wear characteristics of Calophyllum inophyllum and palm biodiesel. Ind. Crop. Prod. 2016, 83, 470-483. [CrossRef]

40. Barsari, M.A.N.; Shirneshan, A. An Experimental Study of Friction and Wear Characteristics of Sunflower and Soybean Oil Methyl Ester under the Steady-State Conditions by the Four-Ball Wear Testing Machine. J. Tribol. 2018, 141, 24. [CrossRef]

41. Singh, Y.; Singla, A.; Singh, A.K. Tribological characteristics of Mongongo-oil-based biodiesel blended lubricant. Energy Sources Part A Recovery Util. Environ. Eff. 2017, 39, 332-338. [CrossRef]

42. Alves, S.M.; De Farias, A.C.M.; Mello, V.S.; Oliveira, J.J. Effect of soybean biodiesel addition on tribological performance of ultra-low sulfur diesel. J. Tribol. 2018, 141. [CrossRef]

43. Hulwan, D.B.; Joshi, S.V. Performance, emission and combustion characteristic of a multicylinder DI diesel engine running on Diesel-Ethanol-Biodiesel blends of high ethanol content. Appl. Energy 2011, 88, 5042-5055. [CrossRef]

44. Wain, K.S.; Perez, J.M.; Chapman, E.; Boehman, A.L. Alternative and low sulfur fuel options: Boundary lubrication performance and potential problems. Tribol. Int. 2005, 38, 313-319. [CrossRef]

45. Zulkifli, N.W.M.; Azman, S.S.N.; Kalam, M.A.; Masjuki, H.H.; Yunus, R.; Gulzar, M. Lubricity of bio-based lubricant derived from different chemically modified fatty acid methyl ester. Tribol. Int. 2016, 93, 555-562. [CrossRef]

46. Nikanjam, M.; Henderson, P.T. Lubricity of low sulfur diesel fuels. SAE Tech. Pap. 1993, 1-9. [CrossRef] 
47. Habibullah, M.; Masjuki, H.H.; Kalam, M.A.; Gulzar, M.; Arslan, A.; Zahid, R. Tribological Characteristics of Calophyllum inophyllum-Based TMP (Trimethylolpropane) Ester as Energy-Saving and Biodegradable Lubricant. Tribol. Trans. 2015, 58, 1002-1011. [CrossRef]

48. Masjuki, H.H.; Maleque, M.A. Investigation of the anti-wear characteristics of palm oil methyl ester using a four-ball tribometer test. Wear 1997, 206, 179-186. [CrossRef]

49. Shahabuddin, M.; Masjuki, H.H.; Kalam, M.A.; Bhuiya, M.M.K.; Mehat, H. Comparative tribological investigation of bio-lubricant formulated from a non-edible oil source (Jatropha oil). Ind. Crop. Prod. 2013, 47, 323-330. [CrossRef]

50. Sperring, T.P.; Nowell, T.J. SYCLOPS—A qualitative debris classification system developed for RAF early failure detection centres. Tribol. Int. 2005, 38, 898-903. [CrossRef]

Publisher's Note: MDPI stays neutral with regard to jurisdictional claims in published maps and institutional affiliations.

(C) 2020 by the authors. Licensee MDPI, Basel, Switzerland. This article is an open access article distributed under the terms and conditions of the Creative Commons Attribution (CC BY) license (http://creativecommons.org/licenses/by/4.0/). 